Acta vet. scand. 1961, 2, 214-225.

From the Department of Animal Husbandry University of California, Davis, California.

\title{
ACETATE METABOLISM IN BOVINE, FASTING KETOSIS
}

By

M. G. Simesen ${ }^{1}$ ), J. R. Luick, Max Kleiber and Christian Thin ${ }^{2}$ ).

Fasting (starvation) ketosis has been studied and reviewed by Robertson and Thin (1953) who showed that cows in late pregnancy and especially at peak lactation respond to fasting in a manner entirely different from that found in the non-pregnant cow, steer, man, dog and rat.

Lactating cows show a rapid and significant fall in milk yield, a sharp fall in rumen volatile fatty acids (roughly proportional to their initial concentrations), an increase in $\mathrm{pH}$ of rumen content, and a steady increase in total ketone bodies in the blood, rumen and milk during the period of fast. The proportions, of $\beta$-hydroxybutyric acid, compared to the other fractions, decreases over the same period. A similar situation occurs in spontaneous ketosis, but a considerably larger proportion of isopropanol is found in the blood, rumen and urine (Thin and Robertson 1953).

The changes in milk composition during fasting and spontaneous ketosis are also similar and are characterized by a marked reduction in the short chain fatty acid content (Smith \& Dastur 1938, Shaw et al. 1942).

1) On leave from the Royal Veterinary and Agricultural College, Copenhagen; appointment supported by the International Co-operation Administration under the Visiting Research Scientists Programm administered by the National Academy of Sciences of the United States of America.

2) Present adress: Department of Veterinary Hygiene and Preventive Medicine. Royal (Dick) School of Veterinary Studies. Edinburgh.

This research was supported by a grant from the U.S. Atomic Energy Commision. 
The biochemical changes in acetate metabolism during spontaneous ketosis have already been studied by Macleod and Luick (1955) and by Kronfeld et al. (1959). The present paper describes a similar study on acetate metabolism in fasting ketosis.

\section{EXPERIMENTAL PROCEDURES}

Data describing the cows are presented in Table 1.

Table 1.

Description of cows.

\begin{tabular}{|c|c|c|c|}
\hline & XXIX & \multicolumn{2}{|c|}{$\mathrm{XXX}$} \\
\hline weight before fasting & $472 \mathrm{~kg}$. & 413 & kg. \\
\hline$川 \quad$ after & $400 \%$ & 390 & , \\
\hline milk- (before fasting (kg./day) & $7-8$, & $8-10$ & , \\
\hline 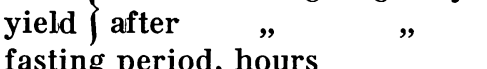 & $3-4$, & $4-5$ & " \\
\hline injected dose of Acetate-1-C ${ }^{14}$ & $2.12 \mathrm{mc}$ & 4.24 & mc \\
\hline
\end{tabular}

Trial XXIX: Jersey cow. No. 119. Fasted from June 26. to 29. During the trial she was very apathic, even somnolent. At the start of the trial her milk showed a strongly positive reaction for ketone bodies. The blood level of ketone bodies varied during the trial from $30-50 \mathrm{mg} . \%$. The blood glucose varied from $16-54 \mathrm{mg} . \%$.

Trial XXX: Jersey cow No. 130. Fasted from December 10. to 14. Her milk was slightly positive for ketone bodies $12 / 15$, moderate on the day of injection (12/16) and strongly positive the same evening. The level of blood ketones ranged from $20-30 \mathrm{mg} . \%$. Her blood sugar concentration varied during the trial from $57-86 \mathrm{mg} . \%$.

The technique for conducting tracer experiments with intact cows has been described by Kleiber and Edick (1952). Following injection of C-1 labeled acetate continuous samples of respired air were taken for the first 3 hours, and then for short periods at intervals up to 48 hours. The cows were milked out at 3,10 , 24,36 , and 48 hours after injection. The procedures for separating milk constituents have been published by Kleiber et al. (1952), those for isolation af glucosazones from plasma by Baxter (1955). For isolation of ketone bodies a method similar to the one used by Kronfeld and Kleiber (1959) for milk ketone bodies was employed.

All the samples were combusted and the resultant carbon dioxide was trapped as bariumcarbonate. This was planchetted and counted at "infinite thickness".

For comparison between animals the standardized specific 
activity has been calculated by dividing the specific activity in the samples $(\mu \mathrm{c} / \mathrm{g}$. atom carbon) by the tracer dose per $\mathrm{kg}$. body

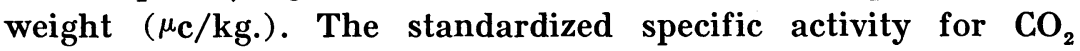
is expressed as $\varrho_{s}$, and the mean has been calculated thus $\bar{\varrho}_{s}=\frac{1}{t} \int_{0}^{t} \varrho_{s} \cdot d t$ where $d t$ is the interval of time corresponding to each value of $\varrho_{s}$ and $t$ is the total time relevant to the mean. The standardized specific activities of milk constituents are represented by $\lambda_{s}$, those of plasma constituents by $\pi_{s}$ and those of urine by $\varepsilon_{\mathrm{s}}$. The means are calculated as $\bar{\lambda}_{\mathrm{s}}=\frac{1}{\mathrm{t}} \sum \lambda_{\mathrm{s}} \cdot \Delta \mathrm{t}$.

\section{RESULTS}

Respired $\mathrm{CO}_{2}$. The time course of appearance of $\mathrm{C}^{14}$ in $\mathrm{CO}_{2}$ is shown in Figure 1. The maximum specific activity occurred after 20-24 min. This indicates a considerable delay compared with the time peak observed in normal cows (8-12 min.). Spon-

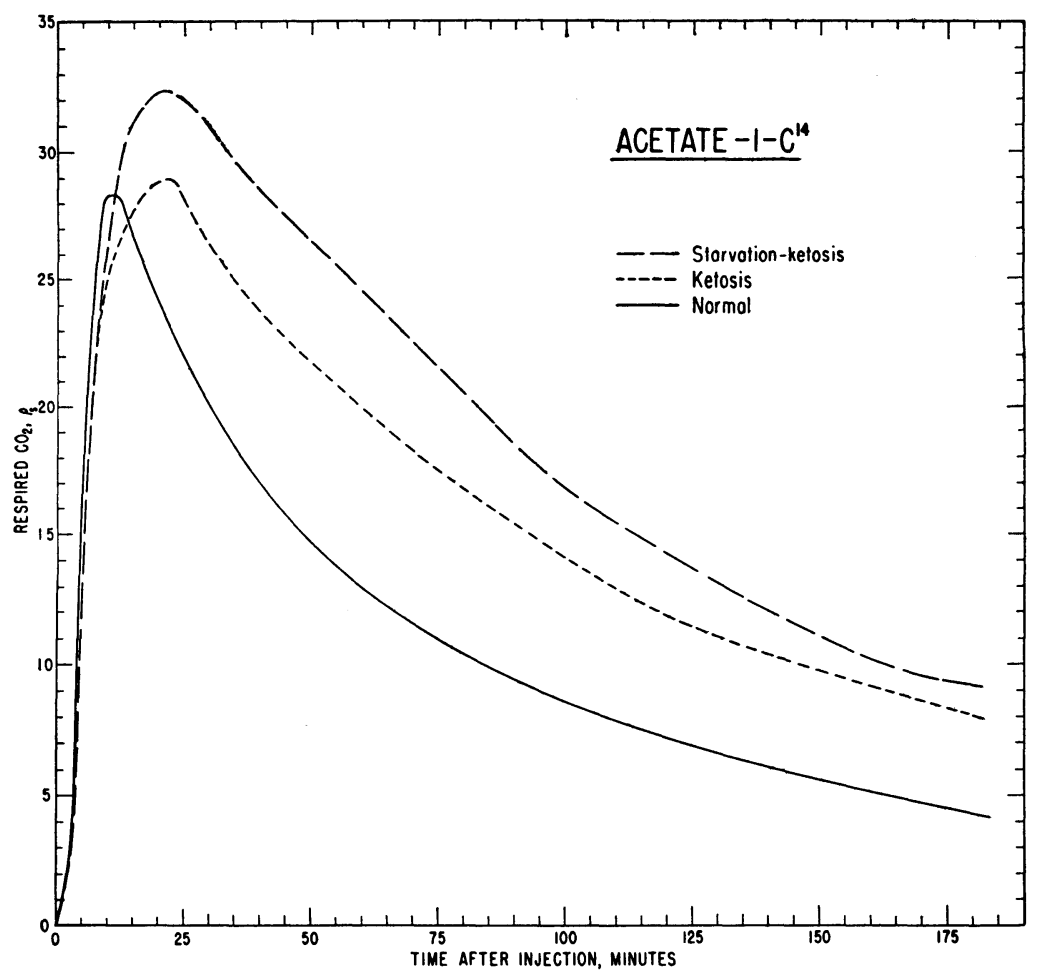

Fi g. 1. Standardized specific activity in respired $\mathrm{CO}_{2}$ after i.v. injection of acetate-1- $\mathrm{C}^{14}$ into cows. 
taneous ketosis showed a similar but less pronounced delay (max. 15-25 min.). In both cases of fasting ketosis the standardized specific activity reached a level higher than that observed in normal or spontaneously ketotic cows, which were both very similar. The mean standardized specific activity over the first three hours was $\mathbf{1 8 . 9}$ for fasting cows compared with $\mathbf{1 6 . 2}$ for spontaneously ketotic and $\mathbf{1 1 . 0}$ for normal cows.

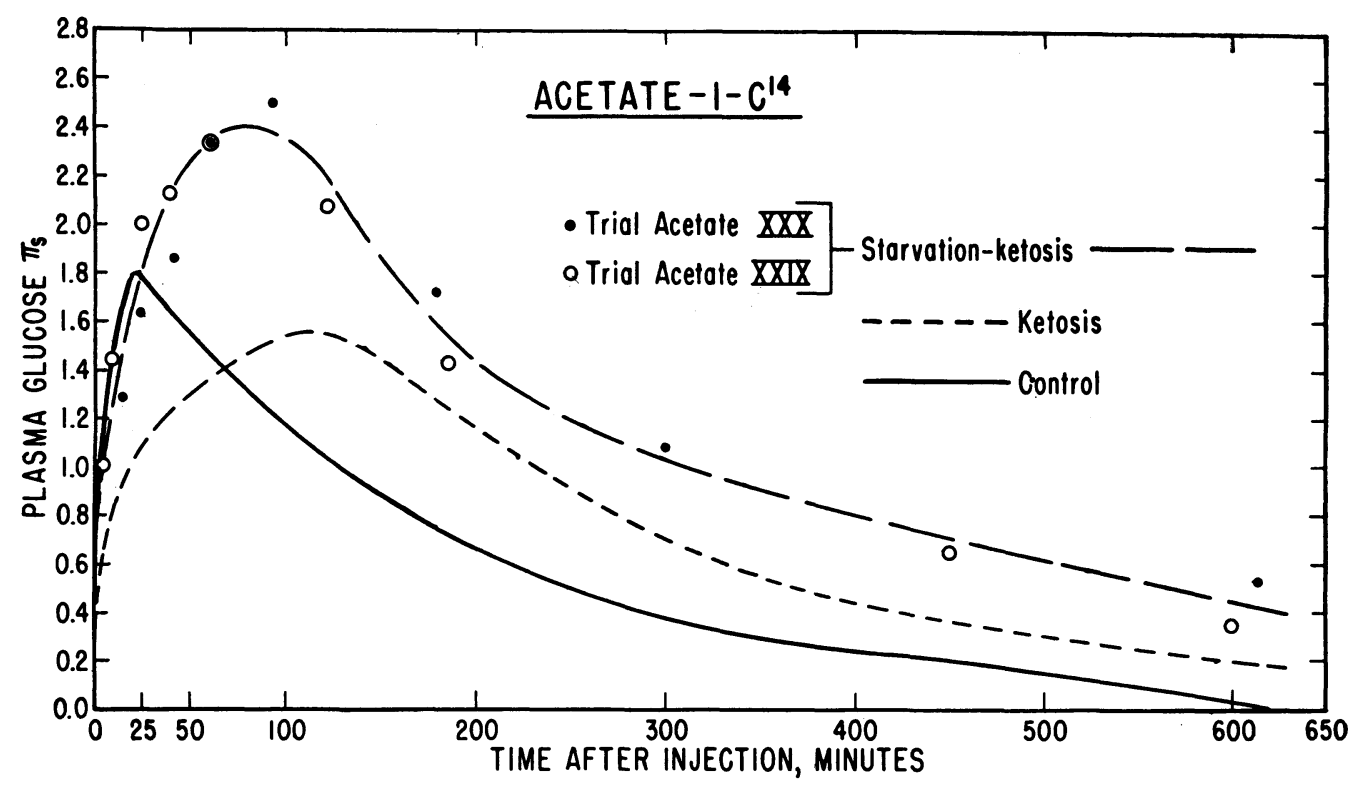

Fi g. 2. Standardized specific activity in plasma glucose after i.v. injection of acetate-1-C 14 into cows.

Plasma glucose. The time course of $\mathrm{C}^{14}$ appearance in plasma glucose is shown in figure 2. A pronounced delay in the maxima $(60-90 \mathrm{~min}$.) were observed in the fasted cows compared to the maxima found in normal cows (15-25 min.). Spontaneous ketosis showed a similar but more pronounced delay (100-120 min.). There was a deviation in magnitude between the normal and the spontaneously ketotic cows, but the total area under the curve is greater during ketosis (1.4 times normal). In fasting ketosis, however, the maximum values are considerably higher, and the area under the curve is approximately 2.3 times larger than the normal. The mean standardized specific activities are given in Table 4 . 
Milk constituents. No delay in the maximum specific activity of any of the milk constituents has been shown. The mean standardized specific activity during the 48 hours after injection of acetate-1- $\mathrm{C}^{14}$ was lower than normal in the fat, but higher in lactose, citrate and, to a lesser extent, in protein (Table 2). The fraction of the dose of $\mathrm{C}^{14}$ recovered from all the milk constituents during 48 hours was approximately $30 \%$ of what was found in the normal cows hereby bringing the per cent recovery very close to what was found during spontaneous ketosis. The index for acetate lipogenicity (the ratio comparing $\mathrm{C}^{14}$ transfer to fat with its transfer to lactose) shows acetate to be far more lipogenic in normal cows than in cows with either fasting or spontaneous ketosis. In both cases of ketosis the shift was brought about by the pronounced decrease in the $\mathrm{C}^{14}$ content of the milk fat.

Table 2.

Radioactivity in milk constituents during 48 hours after acetate 1-C-14 injection.

1) Percentage of injected dose.

\begin{tabular}{lcccc}
\hline & $\begin{array}{c}\text { Normal } \\
\text { aver. VI \& XIII }\end{array}$ & \multicolumn{2}{c}{ Fasting ketosis } & $\begin{array}{c}\text { Ketosis } \\
\text { XXX }\end{array}$ \\
Milk fat & 14.63 & 4.66 & 3.15 & 2.19 \\
Lactose & 1.74 & 1.51 & 1.20 & 2.16 \\
Casein & 1.33 & 0.86 & 0.75 & 0.83 \\
Albumin & 0.24 & 0.17 & 0.16 & 0.20 \\
Citrate & $\left.0.24^{1}\right)$ & 0.18 & 0.14 & 0.23 \\
\hline Total & 18.18 & 7.38 & 5.40 & 5.61 \\
Total fat/lactose & 8.41 & 3.09 & 2.63 & 1.01
\end{tabular}

2) Mean standardized specific activity.

\begin{tabular}{lcccc}
\hline & Normal & \multicolumn{2}{c}{ Fasting ketosis } & Ketosis \\
MI \& XVIII & XxIX & XXX & XIX \& XX \\
Lactose & 0.70 & 0.32 & 0.24 & 0.13 \\
Casein & 0.18 & 0.33 & 0.34 & 0.34 \\
Albumin & 0.16 & 0.15 & 0.23 & 0.27 \\
Citrate & 0.16 & 0.20 & 0.26 & 0.13 \\
Fat/lactose & $\left.0.69^{1}\right)$ & 0.98 & 1.05 & 0.72 \\
\hline
\end{tabular}

1) Trial XVIII only.

Urine ketone bodies. The urine flow, concentration of ketone bodies and their standardized specific activities are given in Table 3. The mean specific activity for the first 4 hours after injection is similar to the value found in spontaneous ketosis. 
Table 3 .

Urine Ketone Bodies.

\begin{tabular}{lcccccccc}
\hline Cow & $\begin{array}{c}\text { Sample } \\
\text { hrs. }\end{array}$ & $\begin{array}{c}\text { Total urine } \\
\text { flow }\end{array}$ & ml./min. & Conc. & mg./100 ml & \multicolumn{2}{c}{ Stand. $s p e c$. act. } \\
AAA & BOH') & AAA & BOH \\
XXIX & $0-3$ & 585 & ml. & 3.2 & 16.0 & 22.2 & 6.11 & 5.72 \\
& $3-10$ & 1150 & $\#$ & 2.7 & 22.1 & 21.2 & - & 0.59 \\
XXX & $0-3$ & 179 & $\#$ & 1.0 & 95.3 & 44.3 & 3.51 & 3.51 \\
& $3-10$ & 300 & $\#$ & 0.7 & 60.0 & 63.3 & 3.02 & 2.77 \\
\hline
\end{tabular}

1) Acetone plus acetoacetate. 2) $\beta$-hydroxy-butyrate.

Table 4 .

Mean standardized specific activity of blood glucose and urine ketone bodies for the first $4 \mathrm{hrs}$. after acetate-1-C-14 injection.

\begin{tabular}{llcc}
\hline & Normal & Fasting ketosis & Ketosis \\
Ketone bodies & 2.5 & 7.9 & 7.4 \\
Glucose & 1.09 & 1.88 & 1.29 \\
Ketone bodies/Glucose & 2.3 & 4.2 & 5.7 \\
\hline
\end{tabular}

\section{DISCUSSION}

Hypoglycemia and liver glycogen depletion as well as the successful use of glucose injections in therapy, have been repeatedly observed in cows suffering from spontaneous ketosis. Therefore ketosis has been attributed to a shortage of body carbohydrate.

This concept of glucose being in critical supply in ketotic cows was followed by the hypothesis of an oxalacetate shortage (Dye et al. 1953, Adler et al. 1956, Marshak 1958, Spörri 1958). According to this idea a glucose shortage is followed by a shortage of oxalacetate. The initial reaction in the tricarboxylic acid (TCA) cycle is a condensation between oxalacetic acid and acetyl-CoA to form citric acid and regenerate CoA. If there were a shortage of oxalacetic acid during ketosis there would follow a decrease in TCA cycle activity.

The quantitatively important pathways open to acetate are shown in Figure 3, the point at which oxalacetic acid shortage would become evident is indicated at (a).

Some experiments have supported the concept of impaired TCA cycle activity:

1. Oxalacetic acid and pyruvic acid administration to fasted, and ketotic sheep, raised the blood glucose concentration and lowered the level of blood ketone bodies (Ho and Reber 1957). 


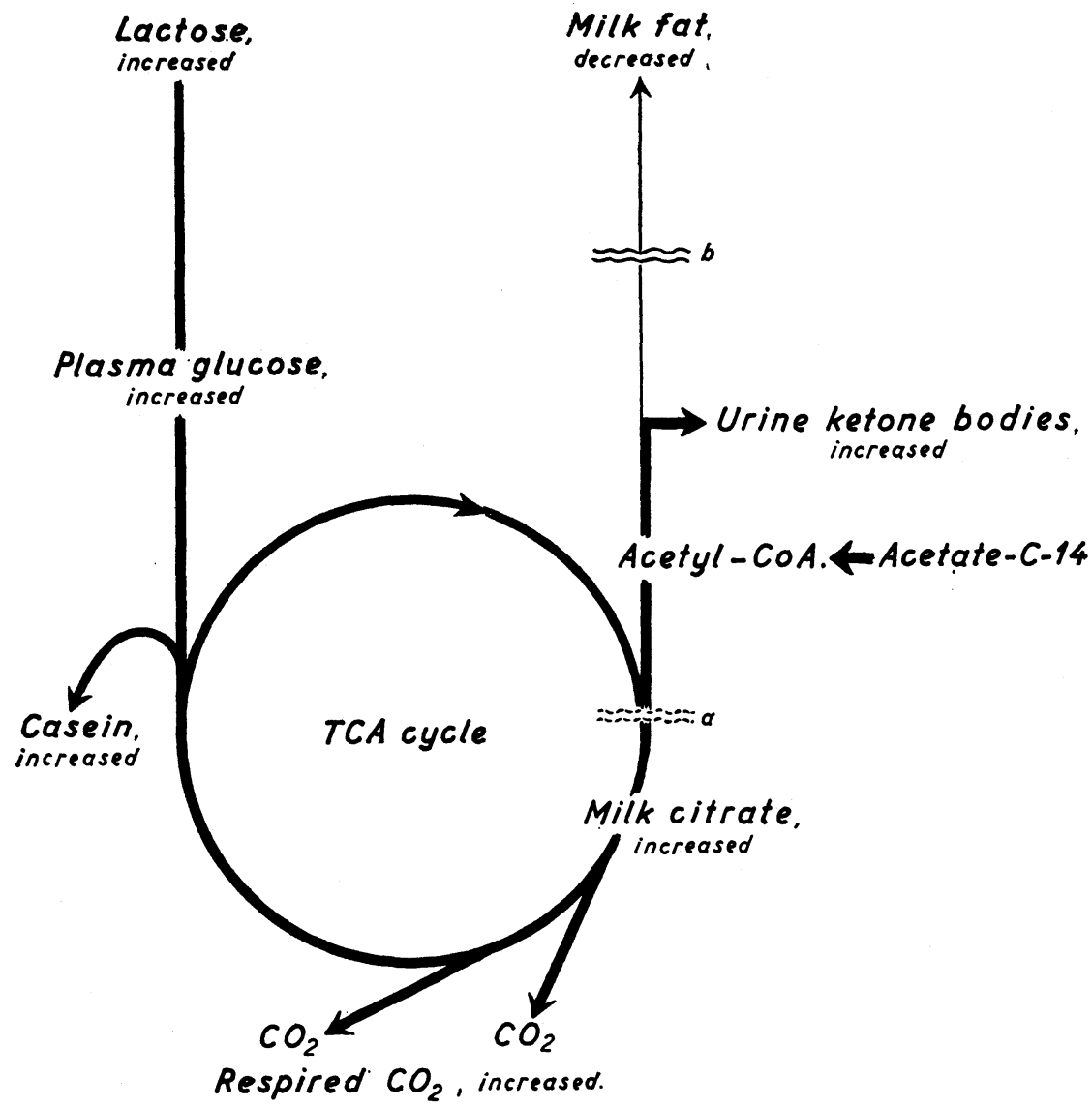

Modified from D.S.Kronfeld, 1959.

2. Peeters et al. (1958) found a decreased acetylation of sulfonamide in ketotic cows. According to these authors this might be due to either a decreased activity of enzymes (or coenzymes), a diminished supply of $\mathrm{C}_{2}$ compounds, or a shortage of energyrich phosphate bonds (ATP).

3. Bach and Hibbitt (1959) found in bovine ketosis that the serum concentrations of pyruvate and $\alpha$-ketoglutarate were increased several hundred per cent above normal, while the amounts of citrate and succinate were decreased. They concluded, that an interference with the TCA cycle might occur, not due to a shortage of oxalacetate, but due to a deficiency in cofactors common in the reactions involved. The suspected cofactors were CoA and ATP. 
Studies with normal cows have led to results consistent with the transfer of acetate $\mathrm{C}^{14}$ to $\mathrm{CO}_{2}$, glutamic acid, and aspartic acid by way of the tricarboxylic acid cycle (Kleiber et al. 1952 and Black and Kleiber 1957). The labeling pattern of plasma glucose in normal and diabetic men has been found consistent with incorporation of acetate $\mathrm{C}^{14}$ via the TCA cycle (Shreeve and Hennes 1957). Thus in the fasting cow the increased level of $\mathrm{C}^{14}$ activity in respired air, blood glucose and milk lactose indicates a relative increase in acetate traversing the TCA cycle during fasting ketosis. The $\mathrm{C}^{14}$ activity of milk citrate, which may be regarded as a trapped intermediary of the TCA cycle, would indicate a similar increase in the TCA cycle activity in the mammary gland. The delays observed in maximum specific activity of respired $\mathrm{CO}_{2}$ and blood glucose suggest a delay in the TCA cycle activity in ketotic cows despite the higher proportion of acetate metabolized via the TCA cycle.

The most marked result, however, is the diminished recovery of $\mathrm{C}^{14}$ in the milk fat, which appeared even though the milk fat percentage was not reduced. Only $3-5$ per cent of the $\mathrm{C}^{14}$ injected as acetate could be recovered from the milk fat during the first 48 hours compared with about 15 per cent in normal cows.

The results reported here are in essential agreement with the results published by Macleod et al. (1955) and Kronfeld et al. (1959) concerning acetate metabolism in spontaneous ketosis, and we might therefore conclude that:

1. the biochemical lesion underlying fasting ketosis is very closely related, or similar, to the lesion found in spontaneous ketosis,

2. one of the main biochemical lesions during ketosis is impaired lipogenesis in the mammary gland, marked (b) in figure 3. Lipogenesis from acetate is undoubtedly impaired during both fasting and spontaneous ketosis, while the production of ketone bodies is increased. Both $\mathrm{CoA}$ and $\mathrm{DPNH}+\mathrm{H}+$ are required for the formation of ketone bodies from acetyl-CoA, so it appears unlikely that either of these cofactors is deficient during either fasting or spontaneous ketosis. A crucial cofactor in lipogenesis is reduced triphosphopyridine nucleotide $(\mathrm{TPNH}+\mathrm{H}+)$ (Cahill et al. 1958, Siperstein 1959 and Ganguly 1960) which is generated during the oxidation of glucose in the pentose phosphate pathway. This pathway is active in normal cows (Black et al. 1957, 
Fiora Raggi et al. 1961) but appears to be virtually inactive in cows with spontaneous ketosis (Tombropoulus and Kleiber 1961).

A feasible reconciliation between the long-held carbohydrate shortage theory and the present results would be that when insufficient glucose traverses some specific metabolic pathways, such as the pentose phosphate pathway, a shortage of enzymatic cofactors may result and lead to secondary interference with other pathways such as lipogenesis. The ketosis manifests this complex of disturbances.

Table 5.

Standardized specific activity in Milk Constituents $\lambda_{\mathrm{s}}$.

\begin{tabular}{|c|c|c|c|c|c|c|c|}
\hline \multirow{6}{*}{$\begin{array}{l}\text { Milk } \\
\text { constituent } \\
\text { Lactose }\end{array}$} & \multirow{3}{*}{$\begin{array}{c}\text { Sample } \\
\begin{array}{l}\text { M-1 } \\
\text { M-2 }\end{array}\end{array}$} & \multirow{2}{*}{\multicolumn{2}{|c|}{$\begin{array}{c}\text { Time from } \\
\text { inj at end } \\
\text { of period } \\
3 \mathrm{hrs} .\end{array}$}} & \multirow{2}{*}{$\begin{array}{c}\text { Trial Xvill } \\
\text { (Normal) } \\
0.53^{1} \text { ) }\end{array}$} & \multicolumn{2}{|c|}{$\underset{\substack{\text { (Starvation } \\
\text { ketosis) }}}{\text { XXXX }}$ XXX } & \multirow{2}{*}{$\begin{array}{r}\underset{1}{\mathrm{XX}} \\
\text { Ketosis } \\
0.492\end{array}$} \\
\hline & & & & & 1.194 & 0.992 & \\
\hline & & 10 & , & 0.63 & 0.842 & 0.987 & 1.455 \\
\hline & M-3 & 24 & " & 0.15 & 0.274 & 0.300 & 0.306 \\
\hline & M-4 & 34 & ” & 0.06 & 0.145 & 0.127 & 0.077 \\
\hline & M-5 & 48 & , & 0.02 & 0.083 & 0.072 & 0.072 \\
\hline \multirow[t]{5}{*}{ Citrate } & M-1 & \multicolumn{2}{|c|}{3 hrs. } & 3.20 & 7.360 & 8.231 & 1.710 \\
\hline & M-2 & 10 & ", & 2.08 & 2.288 & 2.552 & 1.280 \\
\hline & M-3 & 24 & , & 0.38 & 0.379 & 0.361 & 0.360 \\
\hline & M-4 & 34 & ” & 0.27 & 0.157 & 0.121 & 0.080 \\
\hline & M-5 & 48 & , & 0.17 & 0.087 & 0.049 & 0.020 \\
\hline \multirow[t]{5}{*}{ Fat } & M-1 & \multicolumn{2}{|c|}{3 hrs. } & 0.435 & 0.071 & 0.193 & 0.056 \\
\hline & M-2 & 10 & " & 1.145 & 0.439 & 0.726 & 0.265 \\
\hline & M-3 & 24 & , & 0.761 & 0.458 & 0.299 & 0.118 \\
\hline & M-4 & 34 & , & 0.414 & 0.338 & 0.095 & 0.051 \\
\hline & M-5 & 48 & " & 0.318 & 0.160 & 0.041 & 0.030 \\
\hline \multirow[t]{5}{*}{ Casein } & M-1 & \multicolumn{2}{|c|}{3 hrs. } & 0.63 & 1.249 & 1.40 & 0.158 \\
\hline & M-2 & 10 & ” & 0.47 & 0.417 & 0.60 & 0.424 \\
\hline & M-3 & 24 & , & 0.12 & 0.010 & 0.12 & 0.097 \\
\hline & M-4 & 34 & , & 0.05 & 0.006 & 0.06 & 0.029 \\
\hline & M-5 & 48 & , & 0.02 & 0.006 & 0.03 & 0.009 \\
\hline
\end{tabular}

1) $\lambda_{s}$ is generally higher in M-1 than M-2 in normal cows.

\section{REFERENCES}

Adler, J. H. \& J. A. Dye: Cornell. Vet. 1956, 46, 58.

Bach, S. J. \& K. G. Hibbitt: Biochem. J. 1959, 72, 87.

Baxter, C. F., M. Kleiber \& A. L. Black: Biochem. biophys. Acta 1955, $17,354$.

Black, A. L. \& M. Kleiber: Biochem. biophys. Acta 1957, 23, 59. 
Black, A. L., M. Kleiber, E. M. Butterworth, G. B. Brubacher \& J. J. Kaneko: J. biol. Chem. 1957, 227, 537.

Cahill Jr., G. F., A. B. Hastings, J. Ashmore \& S. Zottu: J. biol. Chem. 1958, 230, 125.

Dye, J. A., S. J. Roberts, N. Blampied \& M. G. Fincher: Cornell Vet. $1953,43,128$.

Ganguly, J.: Biochem. biophys. Acta 1960, 40, 110.

Ho, P. \& E. F. Reber: Cornell Vet. 1957, 47, 131.

Kleiber, M. \& M. Edick: J. Animal Sci. 1952, 11, 61.

Kleiber, M., A. H. Smidt \& A. L. Black: J. biol Chem. 1952, $195,707$.

Kleiber, M., A. H. Smidt, A. L. Black, M. A. Brown \& B. H. Tolbert: J. biol. Chem. 1952, 197, 371.

Kronfeld, D. S. \& M. Kleiber: J. appl. Physiol. 1959, 14, 1033.

Kronfeld, D. S., M. Kleiber \& J. M. Lucas: J. appl. Physiol. 1959, 14, 1029.

Macleod, G. K. \& J. R. Luick: Proc. West. Div. Amer. Dairy Sci. Assoc. $1955,36,73$.

Marshak, R. R.: J. Amer. vet. med. Ass. 1958, $132,317$.

Peeters, G., W. Oyaert, J. Bouckaert \& H. Haeck: Zbl. Veterinärmed. 1958, 5, 43.

Raggi, F., E. Hansson, M. G. Simesen, D. S. Kronfeld \& J. R. Luick: Res. vet. Sci. 1961, 2, 180.

Robertson, A. \& C. Thin: Brit. J. Nutrit. 1953, 7, 181.

Robertson, A., H. Paver, P. Barden \& T. G. Marr: Res. vet. Sci. 1960, $1,117$.

Shaw, J. C., R. C. Powell (Jr.) \& C. B. Knodt: J. Dairy Sci. 1942, 2.5. 909.

Shreeve, W. W. \& A. L. Hennes: J. Clin. Invest. 1957, 37, 999.

Siperstein, M. D.: Amer. J. Med. 1959, 26, 685.

Schmidt, J. A. B. \& N. Dastur: Biochem. J. 1938, 32, 1868.

Spörri, H.: Schweiz. Arch. Tierheilk. 1958, 100, 348.

Thin, C. \& A. Robertson: J. comp. Paht. 1953, 63, 184.

Tombropoulus, E. G. \& M. Kleiber: Biochem. J. 1961, 80, 414.

\section{SUMMARY}

The metabolism of intravenously injected acetate-1- $\mathrm{C}^{14}$ in bovine fasting ketosis was compared with the acetate metabolism in normal cows and in cows with spontaneous ketosis. The mean standardized specific activity in respired $\mathrm{CO}_{2}$ over the first 3 hours was 18.9 compared with $\mathbf{1 6 . 2}$ for ketotic and $\mathbf{1 1 . 0}$ for normal cows. The mean standardized specific activity in blood glucose and urine ketone bodies over the first 4 hours was $1.88 / 7.9$ compared with $1.29 / 7.4$ in ketotic and $1.09 / 2.5$ in normal cows. Furthermore the mean standardized specific activity of milk citrate, lactose, casein and albumin over the first 48 hours was greater in fasting ketosis than in the normal cows giving a picture similar to that found during spontaneous ketosis. The total $\mathrm{C}^{14}$ recovered in the milk fat within 48 hours was about 4 per cent compared with 14 per cent in the normal cow and 2 per cent 
during spontaneous ketosis. These results suggest that the metabolic lesions in spontaneous and fasting ketosis are very much alike. The results support the theory of impaired lipogenesis and contradict the assumption of decreased tricarboxylic acid cycle activity during bovine ketosis.

\section{ZUSAMMENFASSUNG}

Der Acetatmetabolismus beim Rind während der Hungerketose.

Der Umsatz intravenös injizierten, 1-C ${ }^{14}$ markierten Acetats wurde beim Rind während des Zustandes der Hungerketose untersucht, und die Resultate wurden mit den Ergebnissen verglichen, die bei entsprechenden Versuchen mit normalen Kühen und Kühen mit spontaner Ketose ausgeführt worden waren. Die durchschnittliche spezifische Aktivität in der $\mathrm{CO}_{2}$ der Ausatmungsluft in den ersten drei Stunden nach der Injektion betrug 18.9 im Vergleich zu 16.2 bei Kühen mit spontaner Ketose und $\mathbf{1 1 . 0}$ bei normalen Kühen. Das Verhältnis zwischen der durchschnittlichen spezifischen Aktivität in der Blutglykose und den Ketonstoffen des Harnes in den ersten 4 Stunden nach der Injektion war 1.88/7.9, im Vergleich zu 1.29/7.4 bei Kühen mit spontaner Ketose und 1.09/2.5 bei normalen Kühen. Ferner war die durchschnittliche spezifische Aktivität im Gehalt der Milch an Zitrat, Laktose, Kasein und Albumin in den ersten 48 Stunden nach der Injektion grösser als bei normalen Kühen, entsprach aber ziemlich den bei spontaner Ketose gefundenen Werten. - Die in den ersten 48 Stunden im Fett der Milch feststellbare Menge $\mathrm{C}^{14}$ betrug ungefähr $4 \%$ im Vergleich zu zirka $14 \%$ bei normalen Kühen und zirka $2 \%$ bei Kühen mit spontaner Ketose.

Die Ergebnisse deuten darauf hin, dass die Stoffwechselstörungen, die sich während spontaner Ketose und bei Hungerketose finden, vom selben Charakter sind. Die Resultate stützen ferner die Theorie über „impaired lipogenesis“, und gehen gegen die Annahme, dass die Trikarboxylsäurezyklusaktivität während der Ketose herabgesetzt sein soll.

\section{SAMMENDRAG}

Omsætningen af intravenøst injiceret $1-\mathrm{C}^{14}$ mærket acetat er blevet undersøgt hos kvæg med sultketose og resultaterne sammenlignet med lignende fors $\emptyset \mathrm{g}$ udf $\varnothing \mathrm{rt}$ på normale køer og på køer med spontan ketose. Den gennemsnitlige specifikke aktivitet $\mathrm{i}$ udåndingsluftens $\mathrm{CO}_{2}$ i de første tre timer efter injektionen blev fundet til 18.9 sammenlignet med $\mathbf{1 6 . 2}$ for køer med spontan ketose, og $\mathbf{1 1 . 0}$ for normale køer. Forholdet mellem den gennemsnitlige specifikke aktivitet i blodets glukose og urinens ketonstoffer i de første 4 timer efter injektionen var 1.88/7.9 sammenlignet med 1.29/7.4 for køer med spontan ketose og 1.09/2.5 hos normale køer. Endvidere var den gennemsnitlige specifikke aktivitet $\mathrm{i}$ mælkens indhold af citrat, lactose, casein og albumin i de første 48 timer efter injektionen st $\varnothing$ rre end hos normale køer, men svarende ganske til de værdier, som er fundet ved spontan ketose. - 
Den mængde $\mathrm{C}^{14}$, som kunne genfindes $\mathrm{i}$ mælkens fedt $\mathrm{i}$ de første 48 timer, var omkring $4 \%$ sammenlignet med ca. $14 \%$ hos normale køer og ca. $2 \%$ hos køer med spontan ketose.

Disse resultater tyder på, at de stofskifteforstyrrelser, som findes under spontan ketose og ved sultketose er af samme karakter. Resultaterne understøtter endvidere teorien om „impaired lipogenesis“, og går imod den antagelse, at trikarboxylsyrecyklusaktiviteten skulle være nedsat under ketose.

(Received February 28. 1961). 